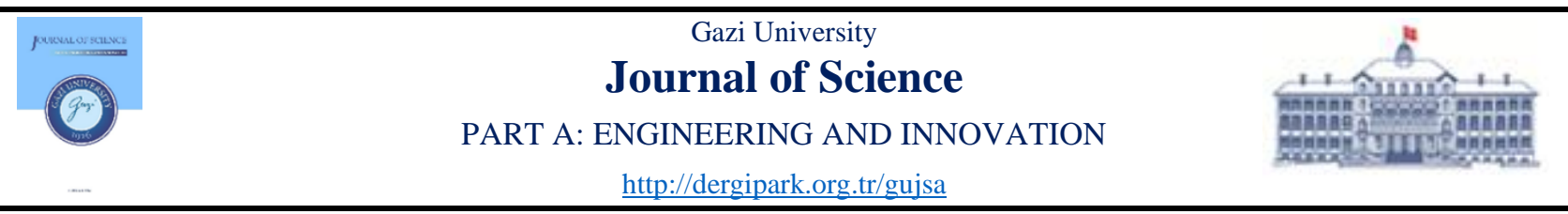

\title{
Evaluation of Student Attitudes Using Multivariate Statistical Analysis
}

\author{
Nurfer Cizmeci ${ }^{* \text { (iD }}$, Fusun Yalcin² \\ ${ }^{1}$ Ministry of Education, Antalya Turkey \\ ${ }^{2}$ Akdeniz University, Faculty of Science, Department of Mathematics, Antalya, Turkey
}

\begin{tabular}{ll}
\hline Keywords & Abstract \\
\hline Multivariate Statistical & $\begin{array}{l}\text { This study aims to classify the high school students' attitudes towards Mathematics and Geometry } \\
\text { Analysis }\end{array}$ \\
Factor Analysis & $\begin{array}{l}\text { difference between several variables determined using t-test. For this purpose, } 1265 \text { students were } \\
\text { selected from } 8 \text { schools in Antalya province using by random sampling method and they were asked to } \\
\text { respond to the survey form given to them. The collected data are classified using Factor Analysis and }\end{array}$ \\
Cluster Analysis & $\begin{array}{l}\text { Cluster Analysis which are among the multivariate statistical methods. According to the factor analysis } \\
\text { Applied Mathematics } \\
\text { results, } 4 \text { factors were determined using the Geometry Attitude Scale, and two factors were determined } \\
\text { by evaluating the Mathematics attitude scale. It was also investigated whether there was a difference } \\
\text { between the attitudes of the students towards mathematics and geometry courses based on the averages } \\
\text { of the responses provided by the students according to the variables of gender, grade level, and } \\
\text { parents' education level. The results of the analyses revealed that there was a significant difference } \\
\text { according to the grade level, while it did not differ according to gender and education level of the } \\
\text { parents. It was observed that the average increased as the grade level increased. }\end{array}$ \\
\hline
\end{tabular}

\begin{tabular}{lcc}
\hline Cite & \\
\hline Cizmeci, N., \& Yalcin, F. (2021). Evaluation of Student Attitudes Using Multivariate Statistical Analysis. GU J Sci, Part A, 8(4), \\
515-528. & Article Process \\
\hline Author ID (ORCID Number) & Submission Date & 17.11 .2021 \\
\hline N. Cizmeci, 0000-0002-5275-6120 & Revision Date & 15.12 .2021 \\
F. Yalcin, 0000-0002-2669-1044 & Accepted Date & 29.12 .2021 \\
& Published Date & 30.12 .2021 \\
\hline
\end{tabular}

\section{INTRODUCTION}

Mathematics and geometry courses are the courses that the students most concerned about at every stage of their education, and their average points are relatively lower. The student's attitude towards a course must be positive to be successful in that course. For this reason, the studies on how to increase the interest of students towards mathematics and geometry courses have been increasing and gaining prominence day by day. The authors applied a t-test in their study to determine the effects of cooperative learning on students' achievement in mathematics and their attitudes towards mathematics courses (Bramlett \& Herron, 2007; Zakaria et al., 2010; Akay, 2011; Avcu \& Avcu, 2015; Moloi, 2019; Berger et al., 2020; Celik, 2020; Ibáñez et al., 2020; Kolaczyk et al., 2020; Moreno-Guerrero et al., 2020). They concluded that cooperative learning methods positively affect the students' achievement in mathematics and their attitudes towards mathematics courses. In his study, the author examined the effect of parent-teacher cooperation on students' achievement in mathematics by using a t-test to analyze the data (Sirvani, 2007). At the end of the study, he concluded that parent-teacher cooperation had a positive effect on students' achievement in mathematics. The authors aimed to examine students' attitudes towards geometry courses according to some variables and they analyzed the data by using ANOVA and t-test methods (Avci et al., 2014). The researchers concluded their study by stating that there was no significant difference between students' attitudes towards geometry course and gender and grade level variables, however, they reported that there was a significant difference between the variables of the students' education field and their school type. In their study carried out at a science high school, the authors aimed to examine students' attitudes towards mathematics course and their academic self- 
designs according to some variables (Pehlivan \& Koseoglu, 2010). They used a t-test, one-way variance analysis, and Scheffe test to analyze the data. At the end of their study, the researchers stated that students' attitudes towards mathematics courses show a significant difference in terms of the variable of gender in favor of the male students and the variable of grade level. However, they concluded that there was no significant difference in terms of the university faculty that the students planned to study. In a study conducted across Turkey, the authors aimed to investigate the students 'attitudes towards mathematics courses and the factors influencing the students 'attitudes towards mathematics courses according to some variables (Yasar et al., 2014). They used One-way Analysis of Variance (One-way ANOVA), Least Significant Difference (LSD) tests and Factor Analysis methods to analyze the data in their study. The researchers concluded their study by reporting that the students' attitudes towards mathematics courses were moderate and the differences between students' attitudes towards mathematics courses by their gender varied according to the region. However, they concluded that students' attitudes towards mathematics courses differ significantly in each region according to the variables of the students' school type and the university entrance exam score type they wanted.

This study is original because it is the first study conducted in Antalya, where students' attitudes towards mathematics and geometry lessons were examined together. In this study, the data obtained from the master's thesis study were used; factor analysis, cluster analysis and t-test were performed and interpreted on these data. The aim of the study was to examine these factors in terms of some variables (gender, class level, education level of parents). In addition, it was aimed to make suggestions to teachers and students based on the findings of the research.

\section{MATERIAL AND METHOD}

The population of this study is composed of the students at the high schools, to which the students were placed by the address-based system, in the central districts of Antalya province in the 2018-2019 academic year. The sample of the study consists of 1320 students at the 10th, 11th, and 12th grades, who were selected using an appropriate sampling method. The study was carried out in the Muratpaşa, Kepez, Konyaaltı, Aksu, Döşemealt1, and Korkuteli districts. A school was selected from each district, but two schools were selected from Muratpaşa and Kepez districts since they were central districts. Exploratory Factor Analysis and Cluster Analysis were applied to determine high school students' attitudes towards Mathematics and geometry courses. For this purpose, a total of 44 items were included in these analyses.

In the study, the students were asked to respond to the scales consisting of three parts. In the first part of the scale, there were questions the about several demographic information. In the second part, the "Attitude Scale towards Geometry Course" developed by Cansiz et al. were used to measure students' attitudes towards geometry course (Aktas \& Aktas, 2013). In the third part, the "Attitude Scale towards Mathematics Course" developed by Askar (1986) was used to measure students' attitudes towards mathematics courses.

After the students were provided with the required information about the study which data collection tools were distributed based on volunteering. The response rate for the survey was found to be $100 \%$. 1265 survey forms that were filled without any mistakes were imported to SPSS 23 software package in the computer environment. Cronbach's Alpha Reliability Coefficients were calculated to test the reliability of the scales. Exploratory factor analysis and cluster analysis were performed to observe, analyze, classify, and compare students' attitudes towards geometry and mathematics courses. Independent sample t-test, one-way analysis of variance, and Kruskal-Wallis (KW) test were conducted to examine whether gender, number of siblings, grade level, and education level of the parents affected students' attitudes towards geometry and mathematics courses.

\subsection{Reliability Analysis}

Reliability analysis is one of the methods to test the power and sufficiency of scales to measure the intended feature. One of the most common methods to test the reliability of a scale is to examine the Cronbach's Alpha Coefficient, which is a measure of the internal consistency of the items (Yildiz \& Uzunsakal, 2018). Cronbach's alpha coefficient of the scale having $\mathrm{k}$ items can be calculated using the following equation 1: 


$$
\alpha=\frac{k}{k-1}\left(1-\frac{\sum_{i=1}^{k} s_{i}^{2}}{s_{k}^{2}}\right)
$$

where $s_{i}^{2}$ stands for variance and $s_{k}^{2}$ stands for the general variance (Ozdamar, 2017). The following assumptions can be made based on the value of the reliability coefficient of $\alpha$. If $\alpha<0.5$, the scale is considered to be unreliable (unacceptable); if it is in the range between $0.5<\alpha<0.6$ the reliability of the scale is considered to be poor; if it is in the range between $0.6<\alpha<0.7$, the reliability of the scale is questionable; if it is in the range between $0.7<\alpha<0.8$, the reliability of the scale is acceptable; if it is in the range between $0.8<\alpha<0.9$, the reliability of the scale is good; it is $0.90<\alpha$, the scale is considered to be highly reliable (Cronbach, 1951).

\subsection{Exploratory Factor Analysis}

Factor analysis is a multivariate statistical method that derives a few uncorrelated variables that are conceptually meaningful from many correlated variables and classifies these variables (Buyukozturk, 2002). In factor analysis, variables with significant correlations between themselves are classified and a few uncorrelated factors are obtained (Mert, 2016). The main purpose of this analysis is to reduce the number of variables and to classify them by obtaining a few significant factors independent of each other from many correlated variables (Kalayci, 2010).Exploratory factor analysis is a method that aims to derive fewer factors by making use of the correlation between the variables in a data matrix (Ozdamar, 2004).If the variance values of the variables are quite different from each other, the correlation matrix is used in the exploratory factor analysis. If data has a homogeneous structure, the covariance matrix is used. The correlation matrix is tested as a whole in the Bartlett's Test of Sphericity, thus, the suitability of the data set for factor analysis is examined Bartlett Sphericity Test requires rejecting the $\mathrm{H}_{0}$ hypothesis which is established as "the correlation matrix is a unit matrix (Bramlett \& Herron, 2007).In other words, it is interpreted that the correlationmatrix is suitable for factoring (Bartlett, 1950; Albayrak, 2006). The hypothesis for Bartlett's Test of Sphericity is as following equation 2 where I denotes the unit matrix and R denotes correlation matrix (Fisher, 1925):

$$
\begin{aligned}
& H_{0}: R=I \\
& H_{a}: R \neq I
\end{aligned}
$$

To determine whether the correlation matrix with $p$ variables of $\mathrm{N}$ units is a unit matrix or not, the $\chi^{2}$ value for the Bartlett's Test of Sphericity statistics is calculated as following equation 3:

$$
\chi^{2}=-\left[n-1-\left(\frac{1}{6}\right)(2 p+5)\right] \ln |R|
$$

where $|R|$ value stands for the natural algorithm of the correlation matrix (Albayrak, 2006). The determinant $|\mathrm{R}|$ of a correlation matrix can be calculated by multiplying all of the eigenvalues showing the contribution rate of factors to the variance (Albayrak, 2006).

Kaiser Meyer Olkin (KMO) Test measures the correlations between variables as a whole and also tests the adequacy of the sample. The KMO value ranges between 0 and 1 . In case a variable in the data set is accurately predicted by other variables, the KMO value is found to be 1 . KMO value is obtained by proportioning the simple correlation coefficient to the partial correlation coefficient (Kalayci, 2010; Alpar, 2017; URL1, 2020)

Kaiser Mayer Olkin sample adequacy measure is calculated as following equation 4 (Cureton \& D'Agostino, 1993; URL1, 2020):

$$
K M O=\frac{\sum_{i \neq j} \sum r_{i j}^{2}}{\sum_{i \neq j} \sum r_{i j}^{2}+\sum_{i \neq j} \sum a_{i j}^{2}}
$$


where $r_{i j}$ denotes a simple correlation coefficient between ith and jth variables, and $a_{i j}$ denotes partial correlation coefficient between ith and jth variables (Cureton \& D'Agostino, 1993; Albayrak, 2006; URL1, 2020). Principal component analysis (PCA) is the most used factor derivation method. The principal component analysis model is established using $\mathrm{m}$ common factors where $\mathrm{k}$ stands for the number of variables and $\mathrm{m}$ stands for the number of factors $(\mathrm{m} \leq \mathrm{k})$. The factor model for the jth variable is established as following equation 5 :

$$
x_{j}=l_{j 1} F_{1}+l_{j 2} F_{2}+l_{j 3} F_{3}+\cdots+l_{j k} F_{k}
$$

where $x_{j}$ denotes jth variable, $\mathrm{F}$ denotes common factors, and 1 denotes the factor loads (Cureton \& D'Agostino, 1993; Albayrak, 2006).

The principal component analysis method initially assumes that the number of variables is equal to the number of factors. It assumes that several of these common factors will explain a significant part of the total variance and the remaining factors will explain specific variances (Albayrak, 2006).

Various approaches such as criteria, graphs, and tests have been developed to determine the number of factors. The most commonly used of these approaches are the variance contribution criterion and the scree test criterion.

\subsection{Cluster Analysis}

As a multivariate statistical method, cluster analysis classifies individuals or objects that are similar by considering variables (Islamoglu, 2009). The groups formed by the cluster analysis are homogeneous among themselves and heterogeneous among other groups. The groups are geometrically distant to each other. The grouping is performed based on the difference in the data, ie. the variance-covariance in factor analysis, and clustering analysis, while the grouping is performed based on the proximity-distance relationship (Hair et al., 2006).The cluster analysis method has four stages: obtaining the data matrix, obtaining and calculating the distance (similarity/difference) matrix, determining the clustering method and creating clusters, and interpreting the results (Alpar, 2017; Ozdamar, 2017).There are a great number of methods to calculate distances between units in cluster analysis. The most commonly used of these methods is the Euclidean distance measure. If the number of units is more than 100, Euclidean distance measurement is recommended to use (Cokluk et al., 2018). In a structure with $\mathrm{k}$ variables, the Euclidean distance measure used to determine the distance between ith and jth units is calculated as following equation 6 :

$$
d_{i j}=\sqrt{\sum_{n=1}^{k}\left(x_{i n}-x_{j n}\right)^{2}}
$$

where $d_{i j}$ denotes the distance between the ith and jth observations, $x_{i n}$ in denotes the value of the nth variable of the ith observation, $x_{j n}$ denotes the value of the nth variable of the jth observation (Anderberg, 1973; Alpar, 2017).

\section{4. t-Test}

$\mathrm{t}$-Test, which is a parametric test, is used when comparing the average of a population with any value. Whether the population meets the assumption of normality should be examined at first as it is a parametric test. However, if the sample is larger than $30(n>30)$ this assumption may not be required (Box, 1987; Mert, 2016). The averages of the data from a sample group or sample groups are compared and analyzed using a ttest. If the data are obtained from two sample groups, the homogeneity of the variances of the means of the sample groups is examined. In case the variances are homogeneous, several types of t-tests can test whether there is a significant difference between the two means. The equality of the sample numbers is important in selecting the relevant test. If the sample numbers are not equal, the total number is important (Box, 1987; 
Cepni, 2010). The t-test statistics are calculated as following equation 7,8,9 based on sample numbers (Box, 1987; Cepni, 2010).

1) t-test to be used when $n_{1}=n_{2}=n$ :

$$
t=\frac{\overline{X_{1}}-\overline{X_{2}}}{\sqrt{\frac{s_{1}^{2}+s_{2}^{2}}{n}}}
$$

2) t-test to be used when $n_{1} \neq n_{2}$ ve $n_{1}+n_{2}<200$ :

$$
t=\frac{\overline{X_{1}}-\overline{X_{2}}}{\sqrt{\left[\frac{\left(n_{1}-1\right) s_{1}^{2}+\left(n_{2}-1\right) s_{2}^{2}}{n_{1}+n_{2}-2}\right]\left(\frac{1}{n_{1}}+\frac{1}{n_{2}}\right)}}
$$

3) t-test to be used when $n_{1} \neq n_{2}$ ve $n_{1}+n_{2} \geq 200$

$$
t=\frac{\overline{X_{1}}-\overline{X_{2}}}{\sqrt{\frac{s_{1}^{2}}{n_{1}}+\frac{s_{2}^{2}}{n_{2}}}}
$$

\section{RESULTS AND DISCUSSION}

Descriptive statistics obtained from the scale applied to determine high school students' attitudes towards mathematics and geometry courses are given in Table 1 . According to this table, $56 \%$ of the students participating in this study are female, 53\% of them have one or two siblings, the mothers of $40.4 \%$ of them have a high school or university degree, and the fathers of $54.4 \%$ of them have a high school or university degree. Also, Muratpaşa ranks first with the participation rate of $27.3 \%$ among the districts where the study was conducted. Then Kepez district ranks second with the percentage of $23.9 \%$. The district with the lowest participation rate is Korkuteli with $9.6 \%$. Considering the participation in the study in terms of grade level, it is seen that there is an almost equal number of 1 participants from the three grade levels involved in the study.

The results of the Keiser-Meyer-Olkin (KMO) test were examined for evaluating the suitability of the sample size to factor analysis. The KMO value was found to be $0.973(97.3 \%)$ for the mathematics attitude scale, and $0.944(94.4 \%)$ for the geometry attitude scale. Moreover, Bartlett's Test of Sphericity was applied to both scales. The results of the test revealed the following values for the mathematics attitude scale: $X^{2}=$ 17800,$958 ; p=0.00<0.01$. For the geometry attitude scale, the following results were obtained: $X^{2}=$ 9213.16; $\mathrm{p}=0.00<0.01$. These results showed that both scales were suitable for factor analysis. Principal Component Analysis was used as the factor deriving method and Varimax Rotation Method was used as the rotation method for both scales. Also, the Cronbach's Alpha Coefficient of the mathematics attitude scale was found to be 0.995 while it was determined to be 0.95 for the geometry attitude scale.

The factors related to high school students' attitudes towards geometry course have the following names: Factor 1: "Self Confidence", Factor 2: "Anxiety", Factor 3: "Usability", and Factor 4: "Significance". The names of the factors related to high school students' attitudes towards mathematics courses are as follows: Factor 1: "Interest", Factor 2: "Anxiety". It was observed that the structures and numbers of the factors obtained by exploratory factor analysis and cluster analysis were the same. Determined by exploratory factor analysis, the factor load values of geometry and mathematics attitude scales are given in Table 2 and Table 3. 
Table 1. Descriptive Statistics

\begin{tabular}{|c|c|c|}
\hline Gender & $\mathbf{n}$ & $\%$ \\
\hline $\begin{array}{l}\text { Female } \\
\text { Male }\end{array}$ & $\begin{array}{l}708 \\
557 \\
\end{array}$ & $\begin{array}{l}56 \\
44 \\
\end{array}$ \\
\hline \multicolumn{3}{|l|}{ Grade Level } \\
\hline $\begin{array}{l}10 \text { th Grade } \\
11 \text { th Grade } \\
12 \text { th Grade }\end{array}$ & $\begin{array}{l}441 \\
436 \\
388 \\
\end{array}$ & $\begin{array}{l}34.9 \\
34.5 \\
30.7 \\
\end{array}$ \\
\hline \multicolumn{3}{|l|}{ School Name/District } \\
\hline $\begin{array}{l}\text { Hacı Şerife Ethem Kavukçu Anatolian High School/Korkuteli } \\
\text { Kepez Anatolian High School/Kepez } \\
\text { Aldemir Atilla Konuk Anatolian High School/Muratpaşa } \\
\text { Halil Akyüz Anatolian High School/Döşemealtı } \\
\text { Akdeniz Anatolian High School/Konyaaltı } \\
\text { Metin Nuran Çakallıklı Anatolian High School/Muratpaşa } \\
\text { Aksu Anatolian High School/Aksu } \\
\text { Atatürk Anatolian High School/Kepez }\end{array}$ & $\begin{array}{l}122 \\
158 \\
180 \\
152 \\
183 \\
166 \\
160 \\
144 \\
\end{array}$ & $\begin{array}{c}9.6 \\
12.5 \\
14.2 \\
12 \\
14.5 \\
13.1 \\
12.6 \\
11.4\end{array}$ \\
\hline \multicolumn{3}{|l|}{ Number of Siblings } \\
\hline $\begin{array}{l}1-2 \\
3-4 \\
5 \text { and above }\end{array}$ & $\begin{array}{c}671 \\
513 \\
81 \\
\end{array}$ & $\begin{array}{c}53 \\
40.6 \\
6.4 \\
\end{array}$ \\
\hline \multicolumn{3}{|l|}{ Education Level of the Mother } \\
\hline $\begin{array}{l}\text { University } \\
\text { High School } \\
\text { Secondary School } \\
\text { Primary School } \\
\text { Uneducated }\end{array}$ & $\begin{array}{c}165 \\
347 \\
286 \\
422 \\
45 \\
\end{array}$ & $\begin{array}{c}13 \\
27.4 \\
22.6 \\
33.6 \\
3.6 \\
\end{array}$ \\
\hline \multicolumn{3}{|l|}{ Education Level of the Father } \\
\hline $\begin{array}{l}\text { University } \\
\text { High School } \\
\text { Secondary School } \\
\text { Primary School } \\
\text { Uneducated }\end{array}$ & $\begin{array}{c}284 \\
403 \\
289 \\
282 \\
7 \\
\end{array}$ & $\begin{array}{c}22.5 \\
31.9 \\
22.8 \\
22.3 \\
0.6 \\
\end{array}$ \\
\hline Total & 1265 & 100 \\
\hline
\end{tabular}

The clusters of the items belonging to the geometry and mathematics attitude scales are given in Table 4 . The items covered by the factors at the end of the exploratory factor analysis and clustering analysis are the same in the mathematics attitude scale, however, there are minor differences in the geometry attitude scale.

The results of sub-factors determined by factor analysis of the scale of high school students' attitudes towards geometry and mathematics course based on several variables are given in Table 5, 6, 7, 8. The significance of the difference between the mean values of the scores of high school students' attitudes towards geometry and mathematics courses by the gender variable has been evaluated using independent samples t-test. As can be seen in Table 5, there is not a significant difference between the students' attitudes towards geometry and mathematics course by gender. 
Table 2. Factor Load Values of Mathematics Attitude Scale

\begin{tabular}{|c|c|c|}
\hline Items & Factor 1 & Factor 2 \\
\hline M14 & 0,784 & 0,383 \\
M13 & 0,747 & 0,415 \\
M11 & 0,731 & \\
M20 & 0,726 & 0,464 \\
M17 & 0,699 & 0,419 \\
M18 & 0,695 & 0,508 \\
M8 & 0,668 & 0,366 \\
M4 & 0,666 & 0,307 \\
M5 & 0,659 & 0,492 \\
M1 & 0,646 & 0,769 \\
M16 & 0,302 & 0,762 \\
M12 & 0,745 \\
M15 & 0,417 & 0,695 \\
M19 & 0,349 & 0,647 \\
M7 & 0,346 & 0,636 \\
M9 & 0,333 & 0,604 \\
M10 & 0,485 & 0,602 \\
M3 & 0,470 & 0,582 \\
M6 & 0,551 \\
\hline
\end{tabular}

Table 3. Factor Load Values of Geometry Attitude Scale

\begin{tabular}{|c|c|c|c|c|}
\hline Items & Factor 1 & Factor 2 & Factor 3 & Factor 4 \\
\hline $\begin{array}{c}\text { G22 } \\
\text { G10 } \\
\text { G19 } \\
\text { G13 } \\
\text { G1 } \\
\text { G7 } \\
\text { G11 } \\
\text { G16 } \\
\text { G14 } \\
\text { G24 } \\
\text { G18 } \\
\text { G12 } \\
\text { G20 } \\
\text { G4 } \\
\text { G15 } \\
\text { G8 } \\
\text { G5 } \\
\text { G9 } \\
\text { G3 } \\
\text { G2 } \\
\text { G23 } \\
\text { G17 } \\
\text { G21 } \\
\text { G6 }\end{array}$ & $\begin{array}{l}0,644 \\
0,633 \\
0,588 \\
0,586 \\
0,558 \\
0,515 \\
0,485\end{array}$ & $\begin{array}{l}0,667 \\
0,640 \\
0,539 \\
0,525 \\
0,516 \\
0,516 \\
0,512 \\
0,366\end{array}$ & $\begin{array}{l}0,699 \\
0,664 \\
0,636 \\
0,608 \\
0,595 \\
0,508 \\
0,461\end{array}$ & $\begin{array}{l}0,679 \\
0,664 \\
0,623\end{array}$ \\
\hline
\end{tabular}


Table 4. Clusters of Items Belonging to Mathematics and Geometry Attitude Scale

\begin{tabular}{|c|c|c|c|}
\hline MAS Items & Clusters & Items & Clusters \\
\hline M1 & 1 & M11 & 1 \\
M2 & 2 & M12 & 2 \\
M3 & 2 & M13 & 1 \\
M4 & 1 & M14 & 1 \\
M5 & 1 & M15 & 2 \\
M6 & 2 & M17 & 2 \\
M7 & 2 & M18 & 1 \\
M8 & 1 & M19 & 1 \\
M9 & 2 & M20 & 2 \\
M10 & 2 & & 1 \\
\hline GAS Items & & G13 & \\
& & G14 & 1 \\
G1 & 1 & G15 & 2 \\
G2 & 4 & G16 & 3 \\
G3 & 3 & G17 & 2 \\
G4 & 2 & G18 & 4 \\
G5 & 3 & G19 & 2 \\
G6 & 4 & G20 & 1 \\
G8 & 1 & G21 & 2 \\
G9 & 3 & G22 & 4 \\
G10 & 3 & G23 & 1 \\
G11 & 1 & G24 & 2 \\
G12 & 1 & & 2 \\
\hline
\end{tabular}

To compare high school students' attitudes towards geometry and mathematics courses by the variable of grade level, one-way analysis of variance was applied where the assumption of homogeneity was provided. Table 6 reveals that the difference by the grade level is not statistically significant in Factor 2 for geometry course.

Table 5. Relationship of Geometry Attitude Scale (GAS) and Mathematics Attitude Scale (MAS) Sub-Factors with the Variable of Gender

\begin{tabular}{|c|c|c|c|c|}
\hline GAS Factors & Gender & Mean \pm SD & $\mathbf{t}$ & $\mathbf{p}$ \\
\hline Factor 1 & Male & $3.26 \pm 0.80$ & 1.90 & 0.057 \\
& Female & $3.17 \pm 0.79$ & & \\
Factor 2 & Male & $3.28 \pm 0.77$ & 1.61 & 0.106 \\
& Female & $3.21 \pm 0.78$ & & 0.200 \\
Factor 3 & Male & $3.39 \pm 0.85$ & 1.28 & 0.654 \\
& Female & $3.32 \pm 0.82$ & & \\
Factor 4 & Male & $3.30 \pm 1.02$ & -0.44 & \\
& Female & $3.33 \pm 1.01$ & & 0.593 \\
MAS Factors & & & & 0.053 \\
& & & -0.53 & \\
\hline \multirow{2}{*}{ Factor 1 } & Male & $3.38 \pm 1.08$ & -1.93 & \\
& Female & $3.41 \pm 1.04$ & & \\
& Male & $3.53 \pm 1.03$ & & \\
& Female & $3.64 \pm 0.98$ & &
\end{tabular}


Table 6. Relationship of Geometry Attitude Scale and Mathematics Attitude Scale Sub-Factors with the Variable of Grade Level

\begin{tabular}{|c|c|c|c|c|}
\hline GAS Factors & Grade Level & Mean \pm SD & F/KW & p \\
\hline Factor 1 & 12th Grade & $3.29 \pm 0.75$ & KW:13.55 & 0.001 \\
& 11th Grade & $3.24 \pm 0.87$ & & \\
Factor 2 & 10th Grade & $3.11 \pm 0.75$ & \multirow{2}{*}{ F:2.42 } & 0.089 \\
& 12th Grade & $3.25 \pm 0.75$ & & \\
& 11th Grade & $3.30 \pm 0.80$ & & 0.015 \\
Factor 3 & 10th Grade & $3.18 \pm 0.78$ & \multirow{2}{*}{ KW:8.39 } & \\
& 12th Grade & $3.45 \pm 0.78$ & & \\
& 11th Grade & $3.36 \pm 0.89$ & & \\
Factor 4 & 10th Grade & $3.26 \pm 0.82$ & KW:8.39 & \\
& 12th Grade & $3.54 \pm 0.91$ & & \\
& 11th Grade & $3.41 \pm 1.01$ & & \\
MAS Factors & 10th Grade & $3.03 \pm 1.04$ & & \\
& & & & \\
\hline Factor 1 & 12th Grade & $3.64 \pm 0.92$ & KW:27.60 & \\
& 11th Grade & $3.31 \pm 1.13$ & & \\
\hline \multirow{2}{*}{ Factor 2 } & 10th Grade & $3.26 \pm 1.05$ & \multirow{2}{*}{ KW:21.25 } & \\
& 12th Grade & $3.80 \pm 0.89$ & & \\
& 11th Grade & $3.53 \pm 1.09$ & & \\
& 10th Grade & $3.47 \pm 0.99$ & & \\
\hline
\end{tabular}

In cases where the homogeneity assumption was not provided, the Kruskal-Wallis (KW) test, one of the nonparametric tests, was applied. Table 6 also reveals that the difference between the grade level is statistically significant for Factor 1, Factor 3, and Factor 4 for geometry course and Factor 1 and Factor 2 for mathematics course $(\mathrm{p}<0.05)$. These differences are in favor of 12 th graders for all factors. Also, it is in favor of the 11th graders compared to the 10th graders. In this case, it was observed that the average score increases as the grade level increases.

To compare high school students' attitudes towards geometry and mathematics courses by the variable of the education level of parents, one-way analysis of variance were applied since the data provided the assumption of homogeneity. Considering Table 7 and Table 8 at the end of this evaluation, it is seen that there is no significant difference in the students' attitudes towards geometry and mathematics by the education level of parents.

It is observed that there is no significant difference between high school students' attitudes towards mathematics and geometry courses by the variables of gender and education level of parents. However, there is a significant difference between all the geometry attitude scale factors, except for the "anxiety" factor, by the variable of grade level. There are similar studies in the literature (Bindak, 2004; Caglayan, 2010; Pehlivan \& Koseoglu, 2010; Yaratan \& Kasapoglu, 2012; Avci et al., 2014; Yasar et al., 2014). In the study conducted by Bindak (2004), the geometry attitude scale was applied to 773 students and the geometry attitude scores of the females were found higher than the scores of the males according to the data. However, it was found that this difference was not statistically significant. Considering the relationship between students' attitudes towards geometry course and the program they wanted to study at the university, it was found that the geometry attitude scores of the students who wanted to study science and medicine were higher than those of the students who wanted to study social sciences, arts, law, and politics. Also, the geometry attitude scores of the students who wanted to study a program that would require geometry found to be higher than those of the students who wanted to study a program that would not require geometry. The study was also concluded that there was no relationship between the socioeconomic levels of families and the students' attitudes towards the geometry course. In the study counducted by collecting data from 553 
students, it was concluded that self-efficacy perception and attitude predicted academic achievement in the geometry course (Caglayan, 2010). When examined in terms of gender, the self-efficacy perceptions and attitudes of female students were found to predict the academic achievement in geometry. While male students' self-efficacy perceptions for geometry courses were found to predict academic achievement in the geometry course, their attitude towards geometry course was found not to predict academic achievement. The study was concluded that the students' self-confidence and motivation towards geometry courses predicted their academic achievement in geometry courses. It was also concluded that the students' selfefficacy perceptions predicted their academic achievement in geometry. However, their perceptions of using geometry knowledge did not predict academic achievement in geometry courses. According to the results of the study conducted by the participation of 345 students by Pehlivan \& Koseoglu, the students' attitudes towards mathematics courses differ by the variable of the gender; it was also concluded that this difference was in favor of male students (Pehlivan \& Koseoglu, 2010).

Table 7. Relationship of Geometry Attitude Scale and Mathematics Attitude Scale Sub-Factors with the Variable of Education Level of Mother

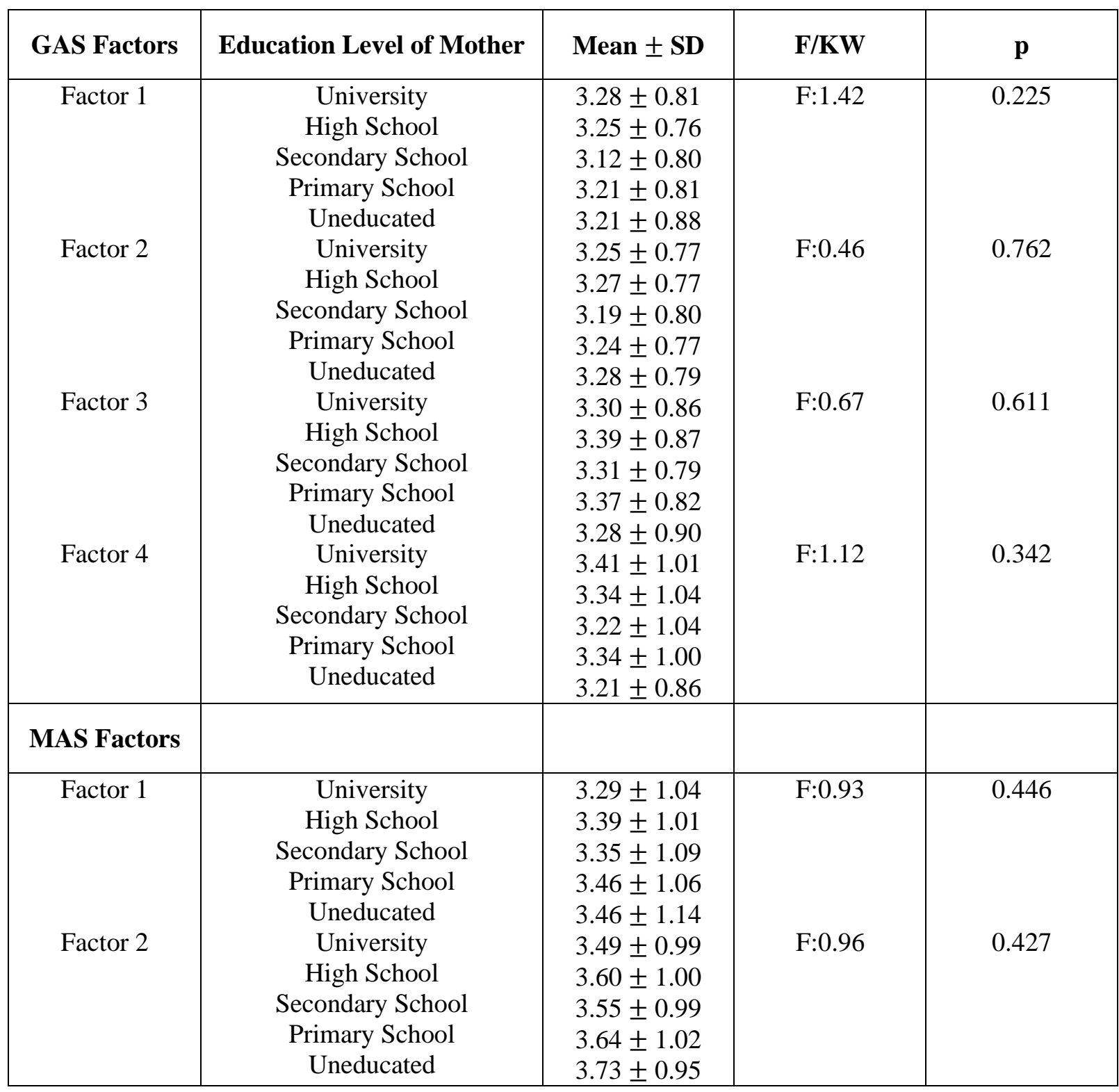

Moreover, a significant difference was found between the students' grade level and their academic achievement in the mathematics course. However, they concluded that there was no significant difference between their achievements by the variable of the university faculty they planned to study. 
Table 8. Relationship of Geometry Attitude Scale and Mathematics Attitude Scale Sub-Factors with the Variable of Education Level of Father

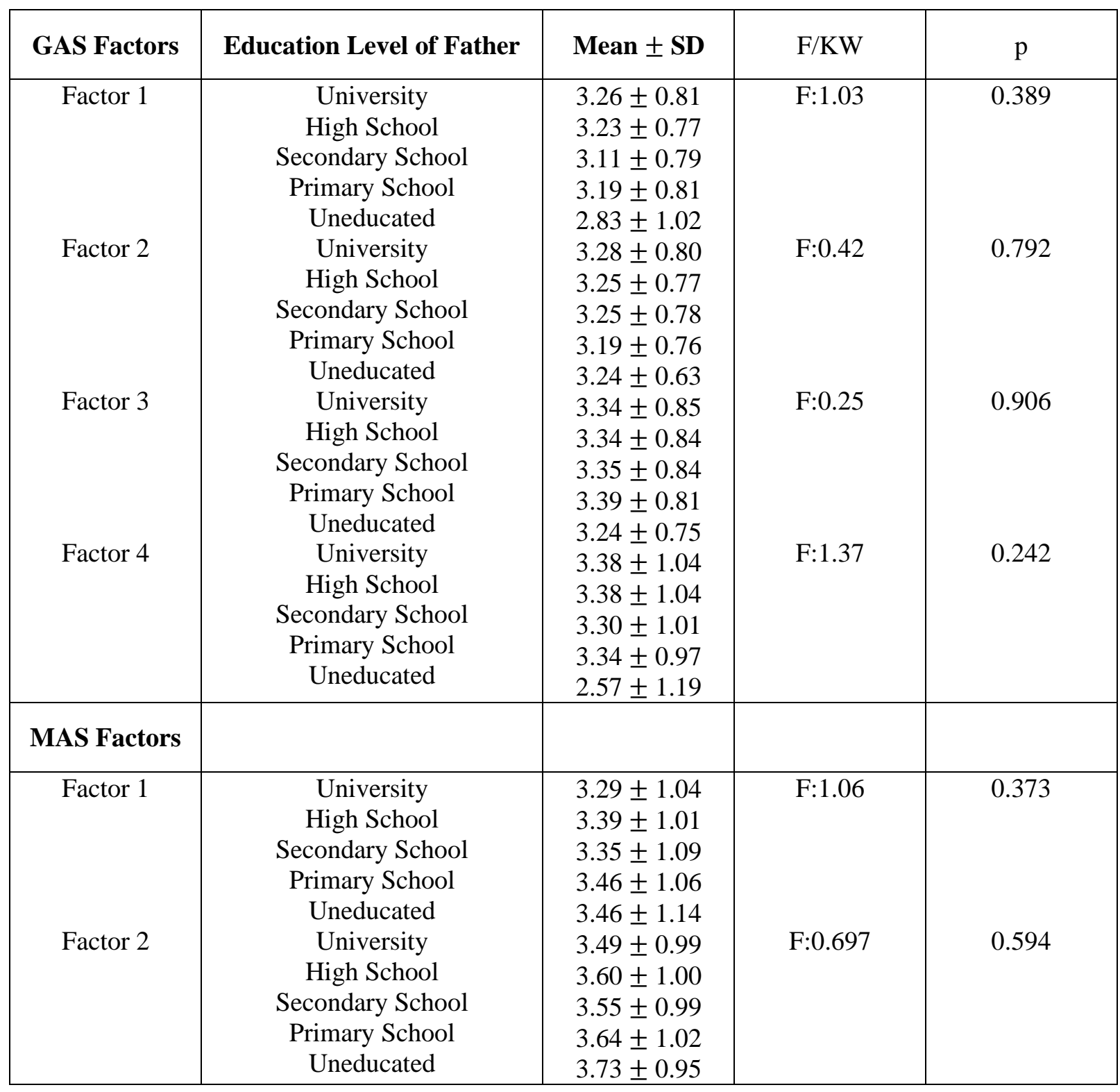

\section{CONCLUSION}

At the end of this study, Cronbach's Alpha Coefficients for the mathematics attitude scale and geometry attitude scale was obtained to be 0.959 and 0.905 respectively. Total variances explained by the mathematics and geometry attitude scales were found to be $61.715 \%$ and $48.866 \%$ respectively. These results are consistent with the results obtained by the other studies in the literature (Askar, 1986; Peker \& Mirasyedioglu, 2003; Kurbanoglu \& Takunyaci, 2012; Aktas \& Aktas, 2013).

Our teachers should play an active role in changing students' attitudes towards courses through education and training. In this context, the scales developed for the courses are of great prominence. Our students' attitudes towards the course should be determined using the developed attitude scales, thus, required arrangements should be introduced for the improvement of education and training activities. In this study, according to results of the factor analysis and cluster analysis obtained from the attitude scale towards mathematics course, two factors, namely interest, and anxiety were determined related to mathematics course, and four factors, namely self-confidence, anxiety, usefulness, and significance, were obtained regarding the geometry attitude scale. These results coincide with similar studies. According to these results, it is thought that the Ministry of National Education (MoNE) and Mathematics teachers should make extra 
efforts to increase the interest in Mathematics and Geometry courses and to relieve the students' anxiety. In this context, the Ministry of National Education is suggested to support and review the studies that investigate students' attitudes towards the course. Mathematics teachers should endeavor to increase the interest in these courses and to relieve the anxiety of the students.

The teachers can begin the lesson with a material that will attract the students' attention. It is recommended that the lessons should be student-centered not teacher-centered. In-class competitions can be organized on the subject of the lesson to make students more active in mathematics lessons.

Course flow programs offered in the Education Information Network of MoNE can be used. Since it is the technology age, the students' interest in the course can be achieved by offering technology in the lesson. Another factor was found to be anxiety. Mathematics course is one of the most challenging courses for the students. This anxiety gradually increases with high school entrance and university entrance exams. Seminars on the subject can be given to the students by the school's counselor to reduce students' anxiety for mathematics and geometry courses. The teachers are recommended to make the students solve a few easy questions on the board in the lesson or to make them participate in the lessons by in-class activities to ensure students' self-confidence against mathematics courses.

\section{ACKNOWLEDGEMENT}

This work was supported by the Akdeniz University Scientific Research Projects (BAP) Coordination Unit with the project number FYL-2019-4384.

\section{CONFLICT OF INTEREST}

No conflict of interest was declared by the authors.

\section{REFERENCES}

Akay, G. (2011). The effect of peer instruction method on the 8th grade students' mathematics achievement in transformation geometry and attitudes towards mathematics. MSc Thesis, Middle East Technical University.

Aktaş, M. C., \& Aktaş, D. Y. (2013). Geometriye yönelik güncel bir tutum ölçeğinin geliştirilmesi. Necatibey Eğitim Fakültesi Elektronik Fen ve Matematik Eğitimi Dergisi, 7(2), 225-247. doi:10.12973/nefmed208

Albayrak, A. S. (2006). Uygulamalı Çok Değişkenli İstatistik Teknikleri. Ankara: Asil Yayın Dağıtım Ltd. Şti.

Alpar, R., (2017). Applied Multivariate Statistical Techniques. Ankara: Detay Yayincilik.

Anderberg, M R. (1973). Cluster Analysis for Applications. Elsevier. doi:10.1016/C2013-0-06161-0

Askar, P. (1986). Developing Attitude Mathematics Scala. Education and Science, 8, 31-36.

Avci, E., Özenir, Ö. S., Coşkuntuncel, O., Özcihan, H. G., \& Su, G. (2014). Ortaöğretim Öğrencilerinin Geometri Dersine Yönelik Tutumları. Turkish Journal of Computer and Mathematics Education, 5(3), 304317.

Avcu, R., \& Avcu, S. (2015). Turkish adaptation of Utley geometry attitude scale: A validity and reliability study. Eurasian Journal of Educational Research, 58, 1-23. doi:10.14689/ejer.2015.58.1

Bartlett, M. S. (1950). Tests of significance in factor analysis. British Journal of Statistical Psychology, 3(2), 77-85. doi:10.1111/j.2044-8317.1950.tb00285.x

Berger, N., Mackenzie, E., \& Holmes, K. (2020). Positive attitudes towards mathematics and science are mutually beneficial for student achievement: a latent profile analysis of TIMSS 2015. The Australian Educational Researcher, 47, 409-444. doi:10.1007/s13384-020-00379-8 
Bindak, R. (2004). Geometri tutum ölçeği güvenirlik geçerlik çalışması ve bir uygulama. PhD Thesis. Dicle University, Diyarbakır.

Box, J. F. (1987). Guinness, Gosset, Fisher, and small samples. Statistical science, 2(1), 45-52.

Bramlett, D. C. \& Herron, S. (2007) A study of African-American college students' attitudes towards mathematics. Journal of Mathematical Sciences and Mathematics Education, 3(2), 43-51.

Buyukozturk, Ş. (2002). Faktör Analizi: Temel Kavramlar ve Ölçek Geliştirmede Kullanımı. Kuram ve Uygulamada Eğitim Yönetimi, 32, 470-483.

Caglayan, O. S. (2010), The capability of high school 1st-grade students' self-efficacy perception and attitude towards geometry course to predict their academic success in the geometry course. MSc. Thesis, Yildiz Technical University, Istanbul.

Celik, H. C. (2020). The effect of modelling, collaborative and game-based learning on the geometry success of third-grade students. Education and Information Technologies, 25(1), 449-469. doi:10.1007/s10639-01909983-3

Cepni, S. (2010). Introduction to research and project. Trabzon: Celepler Publishing.

Cokluk, Ö., Şekercioğlu, G., \& Buyukozturk, Ş. (2018). Sosyal bilimler için çok değişkenli istatistik: SPSS ve LISREL uygulamaları (5. Bask1). Pegem.

Cronbach, L. J. (1951). Coefficient alpha and the internal structure of tests. Psychometrika, 16(3), 297-334. doi: $10.1007 / \mathrm{BF} 02310555$

Cureton, E. E., \& D'Agostino, R. B. (1993). Factor analysis: An applied approach. Psychology press.

Fisher, R. A. (1925). Statistical methods for research workers. Edinburg: Oliver and Boyd.

Hair, J. F., Black, W. C., Babin, B. J., Anderson, R. E., \& Tatham, R. (2006). Multivariate data analysis. Uppersaddle River.

Ibáñez, M. B., Portillo, A. U., Cabada, R. Z., \& Barrón, M. L. (2020). Impact of augmented reality technology on academic achievement and motivation of students from public and private Mexican schools. A case study in a middle-school geometry course. Computers \& Education, 145, 103734. doi:10.1016/j.compedu.2019.103734

Islamoglu A. H. (2009). Research Methods in Social Sciences: (with SPSS applications). Beta Basim Yayim Dagitim A.S.

Kalayci, S. (2010). Multivariate Statistics Techniques with SPSS Applications. Ankara: Dinamik Akademi Yayin Dagitim.

Kolaczyk, E. D., Lin, L., Rosenberg, S., Walters, J., \& Xu, J. (2020). Averages of unlabeled networks: Geometric characterization and asymptotic behavior. The Annals of Statistics, 48(1), 514-538. doi: $10.1214 / 19-A O S 1820$

Kurbanoglu, N. I., \& Takunyaci, M. (2012). An investigation of the attitudes, anxieties and self-efficacy beliefs towards mathematics lessons high school students' in terms of gender, types of school, and students' grades. Journal of Human Sciences, 9(1), 110-130.

Mert, M. (2016) Cross-Sectional Data Analysis Computer Applications. Ankara: Detay Yayincilik.

Moloi, K. (2019). Learners and educators as agents of social transformation in dysfunctional South African schools. South African Journal of Education, 39(1), 1-8. doi:10.15700/saje.v39ns1a1800

Moreno-Guerrero, A. J., Rondon Garcia, M., Martinez Heredia, N., \& Rodriguez-Garcia, A. M. (2020). Collaborative learning based on harry potter for learning geometric figures in the subject of mathematics. Mathematics, 8(3), 369. doi:10.3390/math8030369

Ozdamar, K. (2004). Statistical Data Analysis Using Software Packages (Multivariate Analysis). Eskişehir: Kaan Kitapevi. 
Ozdamar, K. (2017). Structural Equation Modeling for Scale and Test Development. Eskisehir: Nisan Kitabevi.

Pehlivan, H., \& Köseoğlu, P. (2010). Attitudes towards biology course and the academic self concept of the students attending at Ankara science high school. Hacettepe University Journal of Education, 38, 225-235.

Peker, M., \& Mirasyedioglu, S. (2003) The relationship between attudesand successes of high school students for mathematics course, 14(2)157-166.

Sirvani, H. (2007). The effect of teacher communication with parents on students' mathematics achievement. American Secondary Education, 36(1), 31-46.

Yaratan, H., \& Kasapoglu, L. (2012). Eighth grade students' attitude, anxiety, and achievement pertaining to mathematics lessons. Procedia - Social and Behavioral Sciences, 46, 162-171. doi:10.1016/j.sbspro.2012.05.087

Yasar, M., Çermik, H., \& Güner, N. (2014). Türkiye'deki Lise Öğrencilerinin Matematik Dersine İlişkin Tutumları ve Bu Tutumlarını Etkileyen Faktörler. Ankara University Journal of Faculty of Educational Sciences (JFES), 47(2), 41-64. doi:10.1501/Egifak_0000001337

Yildiz, D., \& Uzunsakal, E. (2018). A comparison of reliability tests in field researches and an application on agricultural data. Journal of Business Administration and Social Studies, 2(1), 14-28.

Zakaria, E., Chin, L. C., \& Daud, M. Y. (2010). The effects of cooperative learning on students' mathematics achievement and attitude towards mathematics. Journal of Social Sciences, 6(2), 272-275. doi: $10.3844 /$ jssp. 2010.272.275

URL1: (2020, February 25) https://de.wikipedia.org/wiki/Kaiser-Meyer-Olkin-Kriterium\#Kaiser-MeyerOlkin-Kriterium 